\title{
Virtual Öyrətmə Sistemlərində Proqram Təminatının Xüsusiyyətləri
}

\author{
Әminə A ğazadə \\ AMEA İnformasiya Texnologiyaları İnstitutu, Bak1, Azərbaycan \\ emina635@gmail.com
}

\begin{abstract}
Xülasə- Məqalədə virtual öyrətmə sistemləri xronoloji ardıcılıqla araşdırılmış, onların hər birinin əsas xüsusiyyətlərigöstərilmişdir. Hazırda istifadə edilən 3-cü nəsil virtual öyrətmə sistemlərindəistifadə edilən proqram təminatı sistemləri analiz edilmiş, istifadə edilən şəbəkə vasitələri, Veb xidmətlərdən istifadə standartları tədqiq edilmişdir. Virtual öyrətmə sistemlərinin inkişaf perspektivlərinin əsas istiqamətləri göstərilmișdir.
\end{abstract}

Açar sözlor- virtual öyrotmo sistemlori, virtual öyrotmo sistemlorinin nosillori, virtual öyrotmo sistemlorinin proqram tominatı

\section{GİRIŞ}

Son illərdə rəqəmsal texnologiyaların və telekommunikasiya sistemlərinin inkişafi, kompüter şəbəkələrində informasiyanın həcmi və ötürülmə sürətinin artması,iqtisadiyyatın və ümumdünya əmək bölgüsü sisteminin inteqrasiyası nəticəsində coğrafi yerləşməsindən asılı olmayaraq mütəxəsisə ehtiyacın artması biliklərin yaradılması,ötürülməsi və qəbulu texnologiyalarının tamamilə yeni, elmi-əsaslandırılmış və müasir texniki tərəqqinin tələblərinə cavab verməsi zərurəti yaradır. Hazırda İnternet texnologiyalarında baș verən dəyișikliklər ənənəvi təhsili universitetlərin əhatəsindən çıxarıb "hər yerdə, hamı uçun təhsil"ə çevirmişdir. Bunun nəticəsində biliklərin əldə edilməsi təhsil sistemindən kənarda, yeni transmilli şəbəkə kimi formalaşdı. Bu şəbəkə sürətlə elmi-texniki tərəqqinin tələblərinə uyğunlaşaraq, ənənəvi təhsili əvəz etməklə, özünün yeni standartlarını yaradır.

Virtual öyrətmə sistemi ənənəvi təhsil sisteminin bütün imkanlarını özündə birləşdirən və müasir texnologiyalardan istifadə etməklə istənilən öyrənciyə əlçatan olan və onun arzu və istəklərinə uyğun olaraq dərin bilik verə bilən xüsusi texnobilik sistemidir.

İnkişaf etmiş ölkələrin universitetlərinin demək olar ki, hamısında ənənəvi təhsillə yanaşı təhsilin müxtəlif formalarından istifadə edilir. $\mathrm{Bu}$ təhsil formaları fərqli standartlara əsaslansada, ümumilikdə "virtual öyrətmə sistemi" kimi artıq formalaşmışdır. $\mathrm{Bu}$ sistemlər İnternet yaranan vaxtdan müxtəlif universitetlərdə tətbiq edilir və hazırda dördüncü nəsil virtual öyrətmə sistemləri formalaşma mərhələsindədir [ 1,2].

Birinci nəsil sistemlər sadə şəbəkə və onlayn kursların layihələndirilməsi, yaradılması və istifadəsinə imkan verirdi.
$\mathrm{Bu}$ sistemlərə Hyper Courseware, Lambda MOO, Online Learning Circles, CAPA (Computer Assisted Personalized Approach) system, SUNY (State University of New York) Learning Network və s. sistemləri misal göstərmək olar.

HyperCourseware sistemi elektron təhsil mühitinin bir prototipi kimi hazırlanmışdır. "Tədris Teatrı" adlanan elektron tədris otaqlarından istifadə edilirdi. Məqsəd təhsilə daxil olan prosesləri, alətləri və materialları elektronlaşdırmaq idi. Sistem qisa zamanda geniş əhatə dairəsində istifadə olundu [3].

SUNY (State University of New York) Learning Network sistemi asinxron təhsil posesi tətbiq edilməklə kompüter vasitəsilə onlayn kursların təşkili üçün yaradılmışdır. İlkin variant olaraq 64 sahəni əhatə edirdi. Hal-hazırda sistem OpenSuny adı ilə fəaliyyət göstərir. Osasən Nyu-York Dövlət Universitetinin 3 mindən çox fakültə, 40 kampüsdə $100 \mathrm{~min}$ qeydiyyatı dəstəkləyir [4].

Elementlər arasında inteqrasiya və qarşılıqlı əlaqənin olmamas1, mövcud texnoloji yeniliklərdən istifadənin zəif olması səbəbindən daha mütəhərrik standartların yaradılmas zərurəti yarandı. 1996-cı ilin sonlarında planlaşdırma və administrator əməliyyatlarının aparılması, tədris planlarının və tapşırıqların hazırlanmasının dəstəklənməsi, biliklərin qiymətləndirilməsi və testləşdirilməsi, həmçinin kommunikasiya və digər funksiyaları özündə birləşdirən ikinci nəsil virtual öyrətmə sistemi yarand1. Bu sistemlərdən TELSI (Telematic Environment for Language Simulations) VLE, JISC Technologies Application (JTAP) Programme, WebAssign, Serf, Ucompass.com və s. sistemlər dünyanın bir çox universitetlərinin tədris prosesindəonlayn kursların hazırlanması və virtual öyrətmə sistemi kimi geniş istifadə edildi.Müxtəlif tipli internet telefoniyadan və kompüter audiokonfranslardan istifadə, «tək-tək», «tək-çox» kompüter videokonfransların təşkili, İnternet şəbəkəsində tələbələrin qrup şəklində layihə üzərində, eyni zamanda işləmək imkanlarının zəif olması bu sistemlərin müasir tələblərə cavab vermədiyini müəyyən etmişdir [5].

\section{MÜASIR VİRTUAL ÖYRӘTMӘ SİSTEMLӘRİ}

Hazırda istifadə edilən virtual öyrətmə sistemlərində yuxarıda göstərilən çatışmazlıqlar aradan qaldırılmış və daha müasir proqram təminatı sistemləri yaradılmışdır. Belə sistemlərdən ən çox istifadə edilənlər Blackboard, LMS ANGEL, WebCT, D2L, Moodle sistemləridir. 
ANGELLMS (Learning Management Suite)- Web 2.0 texnologiyaları ssasında hazırlanmış sinxron kommunikasiyaların inteqrasiyasına imkan verən distant təhsil mühitidir.

Moodle (Modular Object Oriented Dynamic Learning Environment) - azad və açıq mənbəlivirtual öyrənmə sistemidir [6].

Proqram MySQL və PostgreSQL verilənlər bazas1 sistemləri əsasında və PHP dilini dəstəkləyən mühitlərdə (Linux, Windows, Mac OS X və s) işləyə bilir.

Moodle proqram təminatı virtual təhsil sistemində istifadə edilə biləcək bir çox xüsusiyyətlərə malik onlayn kurs idarəetmə sistemidir. Moodle hər kəs tərəfindən (müəllim, şagird) asan şəkildə mənimsənilə bilər.

Sistemin ümumi xüsusiyyətləri aşağıdakılardır:

1. Moodle, azad və pulsuzdur;

2. Sistem Windows, Linux, Mac OS $\mathrm{X}$ kimi fərqli əməliyyat sistemlərində işləyə bilir;

3. Təhsil sektorunda geniş tətbiq imkanları vardır;

4. Olduqca geniş tematik biliyə malikdir;

5. 235 ölkədə istifadə edilir və 82 dili dəstəkləyir. Proqram təminatında istənilən dilləri həm eyni anda, həm də tək dili seçmə imkanına malikdir;

6. Açıq mənbəli sistem olduğundan proqram təminatındakı boşluqların müəyyən edilməsi və aradan qaldırılması funksiyası digər sistemlərə nəzərən daha sürətlidir;

7. Sistem ödənişsiz olduğundan əhatə dairəsi çox genişdir;

8. Davamlı olaraq çox sayda yeni xüsusiyyətləri inkişaf etdirilməkdədir və ödənişsiz olaraq bölüşdürülür.

Müasir dövrdə virtual öyrətmə sistemində proqram təminatlarının istifadəsi üçünaşağıdakı proqram və şəbəkə vasitələri mövcuddur:

- Gopher. Şəbəkədə informasiyanın axtarışının menyu sisteminə əsaslanan proqram vasitəsidir.

- WAIS (Wide-Area Information Server). Təbii dil əsasında müxtəlif bazalarda yerləşmiş informasiyanın vahid sorğu əsasında axtarışı və emalını təmin edən vasitələrdən istifadə edən proqram təminatıdır.

- WWW (W3). Şəbəkədə hipermətnlərlə işləməyə imkan verən proqram vasitələridir.

- IRC (Internet Relay Chat).Real vaxt rejimindo dünyanın müxtəlif yerlərində mütəxəsislərlə danışıqlar aparmaq üçün istifadə edilən proqram vasitələrindən ibarət olan şəbəkədir.

- Serverlər. Virtual öyrətmə sistemindəeyni zamanda müxtəlif istifadəçilərin böyük həcmli məlumat bazasında işləməyə imkan verən serverlərdən istifadə edilir. Bu serverlər əsasən xüsusi proqram təminatına malik, informasiya mübadiləsini dialoq rejimində həyata keçirən FTP serverlərdən, yüksək məhsuldarlığa malik digər kompüterlərin hesablama gücündən və proqram təminatından istifadə edərək müxtəlif bazalara girişi təmin edən Telnet serverlərdən və $\mathrm{s}$. ibarət olaraq formalaşmışdır.

- Veb xidmətlər. ABŞ universitetlərində onlayn rejimdə təhsil və tədqiqat nəticələri haqqında məlumatları paylaşmaq üçün dinamik strukturlu Veb xidmətlər kimi Viki sistemdən istifadə edilir [7].

Veb xidmətlərdən aşağıdakı standartlardan istifadə etməklə müxtəlif informasiya sistemlərinin inteqrasiyası nəzərdə tutulur:

$\checkmark$ XML (Extensible Markup Language). İnformasiyanın İnternet vasitəsi ilə göndərilməsi üçün istifadə edilən dildir. Veb xidmətlərdən istifadə zamanı XML dilindən müxtəlif informasiya sistemləri arasında məlumatların mübadiləsi üçün istifado edilir.

$\checkmark$ SOAP (Simple Object Access Protocol). Veb xidmətləri çağırmaq üçün istifadə edilən sadə protokoldur.Bu protokol XML standartı üzərində qurulmuşdur və məlumatın məzmununu ifadə edən konvert formatından, məlumatların tipini müəyyən etmək üçün kodlaşdırma qaydalarından, digər prosedurları çağırmaq üçün qəbul edilən qərarlardan, UDDI (Universal Description, Discovery and Integration) texnologiyalarının yaradılması dilindən - WSDL (Web Services Description Language) ibarətdir. UDDI texnologiyaları təşkilatlarda istifadə edilən Veb xidmətlərinin başqaları üçün də əlçatan olması üçün tətbiq edilir. $\mathrm{Bu}$ texnologiyalar biznes müəssisələrindən (business entity), xidmətlərdən (business servis), əlaqələndirici şablonlardan (binding template) ibarət olaraq qurulur.

\section{MÖVCUD VIRTUAL SISTEMLӘRIN ӘSAS XÜSUSIYYOTLӘRI}

Virtual öyrətmə sistemi dedikdə xüsusi texnoloji və proqram vasitələrindən istifadə etməklə proses iştirakçısının coğrafi yerləşmə məkanından asılı olmayaraq tədris prosesinin aparılmasının təmin edilməsi başa düşülür [8].

Virtual öyrətmə sistemlərinin əsas xüsusiyyətləri aşağıdakılardır:

1. Öyrədən və öyrənənlər arasında əlaqə yaradılması. Sistemlərin əksəriyyətində Wimba,Elluminate, WebEx, Flashmeeting, Acrobat, NetMeeting, Skype sistemlərindən, Call-mərkəzlərdən, elektron poçt, diskusiyalar, wiki, bloqlar və e-portfeldən istifadə edilir;

2. Özünü-qiymətləndirmə və summativ qiymətləndirmə. Məsələn, əksər sistemlərdə avtomatik qeyd və dərhal rəy vasitəsilə çox seçimli qiymətləndirmənin aparılması nəzərdə tutulmuşdur;

3. Tədris resurslarının və materiallarının çatdırılması. Məsələn, mühazirə qeydləri və köməkçi materialların təmin edilməsi vasitəsilə şəkillər və video kliplər, digər İnternet resursları onlayn müzakirələr və qiymətləndirmə vasitələri ilə əlaqələndirilir;

4. İşçi qrupunun sferasının paylaşılması - Təyin olunmuş tələbə qruplarına məlumatları bir-biri ilə paylaşmaq və əlaqə yaratmağa imkan verir; 
5. Tələbələrə dəstək verilməsi. Tədris haqqunda məlumat və tez-tez soruşulan suallar kimi materialların təmin edilməsi vasitəsilə öyrədənlə öyrənənlər arasında əlaqə formalarını təşkil edə bilir;

6. Öyrənənlərin idarə edilməsi və izlənilməsi. Yalnız istifadəçi adı və şifrələrlə təmin olunmaqla qeydiyyatdan keçmiş tələbələr kursa keçid edə bilərlər. Qiymətləndirmənin analizi tələbələr və ya onların istifadə etdiyi materiallar əsasında virtual öyrətmə sistemi vasitəsilə həyata keçirilir;

7. Tələbələrin fərdi veb səhifələri, kurs işlərinin yı ğıldı ğ "damc1 qutuları" (drop boxes), elektron xatırladicilar və təqvimlorin olmas1;

8. Ardıcıl və şəxsiləşdirilə bilən görünüşə malik olması. Standart istifadəçi interfeysi tələbələr üçün asan başa düşülən və istifadə edilən olmalıdır. Kurslar rənglər, qrafiklər və logolar vasitəsilə fərdiləşdirilir, lakin istifadə olunan vacib rejim dəyişilməz olaraq qalır;

9. Naviqasiya strukturunun mövcudluğu. Məlumatların strukturlaşdırılmış şəkildə çatdırılması standart naviqasiya alətlər paneli tərəfindən dəstəklənir. Virtual öyrətmə sistemində əksərproqram təminatı tələbələrin dərs materiallarını xətti ardıcıllıqla yerinə yetirilməsini nəzərdə tutur. Digərləri daha çevikdir və alternativ informasiya strukturlarını yerləşdirmyə imkan verir.

\section{NəTICə}

Hazırda virtual öyrətmə sistemlərində istifadəçinin məqsədlərinin (qoyulan problemi) formalaşdırılmasında yardımçı olmaq üçün biliklərinin təqdimində istifadəçininbilik və hazırlıq səviyyəsinin, sorğu verdiyi sahədə iş təcrübəsinin olması, fərdi xüsusiyyətlərinin nəzərə alınması istiqamətində tədqiqatlar aparılır. $\mathrm{Bu}$ tədqiqatlar əsasında müasir virtual öyrətmə sisteminin yaradılması istiqamətində aşağıdakı layihələrişlənmişdir:

1. SYNAPSE (Systems of Neuromorphic Adaptive Plastic Scalable Electronics) (ABŞ). Bu layihə müxtəlif mənbələrdən bilikləri sərbəst mənimsəyə bilən, mürəkkəb problemlərin həlli üçün qəbuletmə, başa düşmə və qərar qəbuletmə qabiliyyətinə əsasən fərqli informasiyanı kontekstual mənasına görə toplaya bilən intellektual kompüterlərin yaradılmasına əsaslanıb.

2. China Brain Project. Süni beyin yaradılması üzrə işlənilən layihə.

3. OpenWorm. Rəqəmsal orqanizm yaradılması üzrə açıq kodlu beynəlxalq layihə.

4. Human Brain Project (HBP)/ Avropa İttifaq1 tərəfindən maliyyələşdirilir. Məqsəd superkompüterdə tam olaraq insan beyninin modelini yaratmaqdir.

5. Human Connectome Project(HCP). ABŞ-1n Milli Sağlamlıq İnstitutu tərəfindən həyata keçirilir. Layihənin əsas məqsədi sağlam insan beyni ilə əlaqədar olan anatomik və funksional keçidi işıqlandıran "şəbəkə xəritəsi”ni yaratmaq, həmçinin disleksiya, autizm, alzheimer və şizofreniya kimi beyin pozğunluqlarının öyrənilməsini asanlaşdıran verilənlər korpusunu (a body of data) yaratmaqdır.

\section{ӘDӘВIYYAT}

[1] В. Д. Чухломин, “Как подготовить специалиста мирового класса" ЭКО, 2009, № 6, с.137-141.

[2] Ю. Завдовьева, “Компетенции е-learning специалиста в ВУЗ”,ЕLEARNING PRO, 2009, № 3 c. 38 .

[3] K. L. Norman, "HyperCourseware for interactive instruction in the electronic classroom."// Behavior Research Methods, Instruments \& Computers, (1994), pp. 255-259.

[4] https://navigator.suny.edu

[5] V.Guglielmo, "Virtual Revisions Classes Using a VLE", International Conference on Cognition and Exploratory Learning in Digital Age (CELDA), 2005, pp.423-427.

[6] M.Khabbaz, R. Najjar, "Moodle-based Distance Language Learning Strategies: An Evaluation of Technology in Language Classroom" International Journal of Applied Linguistics \& English Literature, 2015,Vol. 4 No. 4, pp.205-210.

[7] S.Allen, J.Seaman, "Staying the Course: Online Education in the United States in 2008" A Report by SLOAN C Consortium. Boston, 2008, p. 24.

[8] P.Taylor, D.Maor, "Assessing the efficacy of online teaching with the Constructivist OnLine Learning Environment Survey"Proceedings of the 9th Annual Teaching Learning Forum, 2-4 February, 2000, Perth: Curtin University of Technology, p.7 